\title{
Effect of Vitamin D Supplementation on Moderate to Severe Bronchial Asthma: Correspondence 1
}

\author{
Abhishek Arya $\cdot$ Atul Jindal \\ Received: 4 August 2014 / Accepted: 24 December 2014 / Published online: 13 February 2015 \\ (C) Dr. K C Chaudhuri Foundation 2015
}

To the Editor: We read the article "Effect of vitamin D supplementation on moderate to severe bronchial asthma" by Yadav et al. [1] with great interest. The results of this randomized study reaffirm the beneficial role of vitamin $\mathrm{D}$ in the management of moderate to severe asthma.

The authors enrolled 100 patients by randomization into the two different treatment arms of this study. Calculation of appropriate sample size is the initial hurdle that needs to be overcome while planning any randomized trial. The primary outcome measure of the study is the major factor responsible for estimation of the sample size. Change in level of severity of asthma as per the GINA guidelines is the primary outcome measure for this study. The expected change in the severity of asthma should have been first ascertained in the light of various previous studies on the association of vitamin D deficiency in asthmatic children [2-5]. Subsequent calculation of sample size based on this value of change in asthma severity with vitamin D could have resulted in better understanding of the effect size of vitamin D supplementation.

After randomization, one group received oral vitamin D3 (Cholecalciferol) 60,000 IU per month for six months and the other group received placebo powder in the form of glucose sachet. Vitamin D sachet was procured from a pharmaceutical company and the sachet was made opaque in the hospital pharmacy. The placebo group received the glucose powder which was sweeter in nature as compared to powdered vitamin D3. This factor can induce bias in the allocation concealment as an appropriate randomization technique stresses that both the products should have similar color, odor, flavor, appearance, and preferably procured from the same manufacturer.

The authors observed that there was increase in the asthma severity from moderate to severe in the placebo group for five months in the follow up period as shown in table 2; however, table no 4 depicts adequate control of asthma in all the patients from the third month onward. Similarly there was increase in the requirement of mean dose of steroid as shown in the figure 3 . All these contradictory observations can create confusion in the mind of numerous readers regarding the validity of the study results.

Conflict of Interest None.

Source of Funding None.

\section{References}

1. Yadav M, Mittal K. Effect of vitamin D supplementation on moderate to severe bronchial asthma. Indian J Pediatr. 2014;81:650-4.

2. Sandhu MS, Casale TB. The role of vitamin D in asthma. Ann Allergy Asthma Immunol. 2010;105:191-9.

3. Van Oeffelen AA, Bekkers MB, Smit HA, Kerkhof M, Koppelman $\mathrm{GH}$, Haveman-Nies A, et al. Serum micronutrient concentrations and childhood asthma: the PIAMA birth cohort study. Pediatr Allergy Immunol. 2011;22:784-93.

4. Hollams EM, Hart PH, Holt BJ, Serralha M, Parsons F, de Klerk NH, et al. Vitamin D and atopy and asthma phenotypes in children: a longitudinal cohort study. Eur Respir J. 2011;38:1320-7.

5. Freishtat RJ, Iqbal SF, Pillai DK, Klein CJ, Ryan LM, Benton AS, et al. High prevalence of vitamin D deficiency among inner-city African American youth with asthma in Washington, DC. J Pediatr. 2010;156:948-52.

\footnotetext{
A. Arya $\cdot$ A. Jindal $(\square)$

Department of Pediatrics, All India Institute of Medical Sciences, Raipur, Chhattisgarh 492099, India

e-mail: dratuljindal@gmail.com
} 